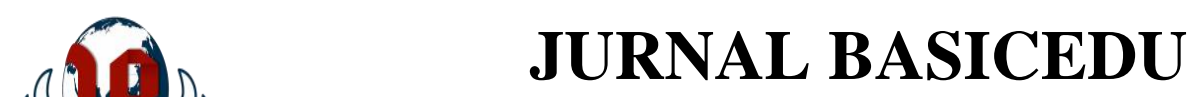

Volume 5 Nomor 4 Tahun 2021 Halaman 1879 - 1887

Research \& Learning in Elementary Education

https://jbasic.org/index.php/basicedu

\title{
Peningkatan Kreativitas Siswa Pada Pembelajaran Tematik Menggunakan Pendekatan Project Based Learning
}

\author{
Lilis Setiawan $^{1 凶}$, Naniek Sulistya Wardani², Trifosa Intan Permana ${ }^{3}$ \\ Universitas Kristen Satya Wacana, Indonesia ${ }^{1,2,3}$ \\ E-mail: setiawanlilis43@gmail.com ${ }^{1}, \underline{\text { naniek.wardani@uksw.edu }}{ }^{2}, \underline{\text { trifosaintanpermana@gmail.com }}^{3}$
}

\begin{abstract}
Abstrak
Penelitan ini bertujuan untuk mengetahui a) apakah terdapat peningkatan kreativitas belajar siswa pada pembelajaran tematik menggunakan pendekatan Project Based Learning? b) bagaimana langkah-langkah pendekatan Project Based Learning yang dapat meningkatkan kreativitas siswa dalam pembelajaran tematik? Subjek penelitian yaitu siswa kelas 5 SD yang berjumlah 21 siswa. Teknik pengumpulan data dalam penelitian ini menggunakan teknik non tes. Instrumen penelitian berupa lembar observasi. Hasil penelitian menunjukkan bahwa terdapat peningkatan kreativitas belajar siswa pada pembelajaran tematik menggunakan pendekatan Project Based Learning ditunjukkan oleh peningkatan kreativitas belajar yakni banyaknya siswa yang memiliki kreativitas tinggi sebelum tindakan sebanyak 7 siswa (33,33\% dari seluruh siswa). Setelah diberikan tindakan pada siklus I, jumlah siswa yang memiliki kreativitas belajar tinggi meningkat menjadi 11 siswa (52,38\% dari seluruh siswa), dan pada siklus II jumlah siswa yang yang memiliki kreativitas belajar tinggi menjadi 17 siswa (80,95\% dari seluruh siswa). Langkahlangkah pembelajaran dengan pendekatan Project Based Learning yang dapat meningkatkan kreativitas belajar siswa yaitu pembelajaran dimulai dengan memberikan pertanyaan, merencanakan proyek pembuatan video percobaan proses perpindahan panas, menyusun jadwal aktivitas selama proses pembuatan video percobaan, mengawasi jalannya proses pembuatan video percobaan, penilaian pada video hasil percobaan, evaluasi hasil percobaan dengan melakukan refleksi terhadap aktivitas percobaan perpindahan panas.
\end{abstract}

Kata Kunci: Kreativitas, Pembelajaran Tematik, Project Based Learning

\begin{abstract}
This study aims to find out a) whether there is an increase in student learning creativity in thematic learning using a Project-Based Learning approach? b) What are the steps of the Project-Based Learning approach that can increase students' creativity in thematic learning? The research subjects were 5th-grade elementary school students who opened 21 students. Data collection techniques in this study used non-test techniques. The research instrument was in the form of an observation sheet. The results showed that there was an increase in student learning creativity in thematic learning using the Project-Based Learning approach which was indicated by an increase in learning creativity, namely the number of students who had high creativity before the action was 7 students (33.33\% of all). After being given action in the first cycle, the number of students who had high learning creativity increased to 11 students (52.38\% of all students), and in the second cycle, the number of students who had learning creativity became 17 students (80.95\% of all students). The learning steps with the Project-Based Learning approach that can improve student learning are learning begins by asking questions, planning a project for making heat transfer video experiments, arranging activity schedules during the process of making experimental videos, supervising the process of making experimental videos, assessing the experimental results videos, evaluate the experimental results by reflecting on the activity of the heat transfer experiment.
\end{abstract}

Keywords: Creativity, Thematic Learning, Project Based Learning

Copyright (c) 2021 Lilis Setiawan, Naniek Sulistya Wardani, Trifosa Intan Permana

Corresponding author :

Email : setiawanlilis43@gmail.com

DOI : https://doi.org/10.31004/basicedu.v5i4.1068

ISSN 2580-3735 (Media Cetak)

ISSN 2580-1147 (Media Online)

Jurnal Basicedu Vol 5 No 4 Tahun 2021

p-ISSN 2580-3735 e-ISSN 2580-1147 


\section{PENDAHULUAN}

Pembelajaran di era abad 21 dituntut agar dapat membiasakan siswa untuk mampu menguasai keterampilan abad 21 (Handajani, Pratiwi, \& Mardiyana, 2018). Keterampilan yang dikembangkan pada abad 21 terdiri dari berpikir kritis dan pemecahan masalah, komunikasi dan kolaborasi, kreativitas dan inovasi (Rusadi, Widiyanto, \& Lubis, 2019). Salah satu keterampilan yang penting untuk dikembangkan dalam pembelajaran yaitu kreativitas siswa (Alzoubi et al., 2016). Kreativitas merupakan keterampilan siswa untuk memunculkan ide, cara, atau model yang baru untuk menyelesaikan suatu permasalahan (Astuti \& Aziz, 2019).

Kreativitas belajar siswa dapat diukur berdasarkan lima indikator yaitu fluency, flexibility, originality, elaboration, dan evaluation (Munandar, 2009). Kelancaran berpikir (fluency) merupakan kemampuan siswa dalam memunculkan banyak pertanyaan, keluwesan berpikir (flexibility) merupakan kemampuan siswa dalam memunculkan penyelesaian dari sudut pandang yang berbeda-beda, keaslian (originality) merupakan kemampuan siswa dalam mencetuskan ide yang dimiliki, kerincian (elaboration) merupakan kemampuan siswa dalam memperinci detail-detail dari suatu objek, gagasan, atau situasi, dan evaluasi (evaluation) merupakan kemampuan untuk mengambil keputusan pada situasi yang terbuka (Agustiana et al., 2020). Indikator tersebut dapat digunakan untuk membedakan tingkatan kreativitas antara siswa satu dengan yang lainnya. Kreativitas siswa memiliki peranan penting untuk menyelesaikan suatu permasalahan yang dihadapi (Ernawati, Asrial, \& Muhaimin, 2019).

Namun fakta dilapangan menunjukkan bahwa kreativitas siswa masih perlu untuk dioptimalkan. Hal tersebut sejalan dengan hasil observasi Nuryati \& Yuniawati (2019) yang menunjukkan bahwa kreativitas siswa SD masih rendah. Sejalan dengan hasil observasi Vera \& Astuti (2019) yang menunjukkan bahwa terdapat masalah kreativitas siswa kelas V SD. Permasalahan tersebut disebabkan oleh beberapa hal yaitu sebagian besar guru masih tidak peduli terhadap kreativitas yang dimiliki siswa, kurangnya minat siswa dalam belajar, dan pelaksanaan pembelajaran yang berpusat pada guru. Sejalan dengan pendapat Wulandari, Mawardi, \& Wardani (2019) yang mengemukakan bahwa rendahnya kreativitas siswa disebabkan oleh penerapan model pembelajaran konvensioanl. Selain itu menurut Mashitoh, Sukestiyarno, \& Wardono (2021) rendahnya kreativitas siswa dikarenakan tidak tersedianya media pembelajaran yang sesuai, kesulitan siswa dalam memahami materi pembelajaran, dan kurangnya pembiasaan siswa dalam menyelesaikan soal non-rutin. Sebagai upaya untuk mengoptimalkan kreativitas belajar siswa maka diperlukan pelaksanaan pembelajaran yang tepat, salah satunya dengan penerapan pembelajaran Kurikulum 2013 (K13).

Pembelajaran K13 bertujuan untuk menghasilkan masyarakat Indonesia yang aktif, produktif, kreatif, dan inovatif (Yuniawardani \& Mawardi, 2018). Pembelajaran tersebut berpusat pada pembelajaran tematik yang menggabungkan anatara mata pelajaran satu dengan yang lainnya ( AM, Saputra, \& Amelia, 2017). Pelaksanaan pembelajaran tematik terpadu di SD di masa pandemi Covid-19 dilaksanakan secara daring. Pembelajaran dalam jaringan merupakan pembelajaran yang dilakukan tanpa tatap muka langsung yang dijembatani melalui media internet dan alat penunjang lainnya seperti telepon seluler atau komputer (Putria et al., 2020). Pelaksanaan daring pada SD dapat dikombinasikan dengan pembelajaran luring, tetapi intensitas pembelajaran daring lebih dominan dibandingkan dengan pembelajaran luring.

Pembelajaran yang terjadi di kelas 5 SD saat ini yaitu kombinasi antara pembelajaran daring dan pembelajaran luring (tatap muka). Pada pelaksanaan pembelajaran daring dilakukan setiap hari dengan cara mengirimkan materi atau tugas menggunakan WhatsApp Group (WAG). Pelaksanaan pembelajaran daring terdapat banyak kendala yang dialami, terutama pada sarana dan prasarana serta antusias siswa terhadap pembelajaran dilaksanakan. Dalam pelaksanaan pembelajaran daring guru masih cenderung mengajar dengan cara konvensional yaitu menerangkan materi yang ada pada buku tematik serta belum menggunakan pendekatan dan metode pembelajaran. Selain itu guru tidak memanfaatkan media pembelajaran seperti powerpoint dalam menunjang proses belajar maupun aplikasi Zoom ketika pembelajaran daring dilakukan. 
1881 Peningkatan Kreativitas Siswa Pada Pembelajaran Tematik Menggunakan Pendekatan Project Based Learning - Lilis Setiawan, Naniek Sulistya Wardani, Trifosa Intan Permana

DOI: https://doi.org/10.31004/basicedu.v5i4.1068

Hasil kreativitas belajar siswa yang dapat dilihat dari pembelajaran pra siklus yaitu kriteria kreativitas tinggi sebanyak 7 siswa (33,33\% dari seluruh siswa). Pendekatan project based learning merupakan pendekatan belajar yang menggunakan masalah sebagai langkah awal dalam pengumpulan dan mengintegrasikan pengetahuan baru berdasarkan pengalamannya dalam beraktivitas secara nyata. (Hariyanto \& Warsono, 2012) mengatakan bahwa project based learning adalah suatu pendekatan yang mengaitkan antara teknologi dengan masalah kehidupan sehari-hari yang akrab dengan siswa, atau dengan suatu proyek sekolah. (Nurul 'azizah \& Wardani, 2019) menjelaskan bahwa project based learning merupakan model pembelajaran inovatif yang memfokuskan pada belajar kontekstual melalui kegiatan yang kompleks. Pendapat di atas dapat disimpulkan bahwa penekanan pendekatan project based learning terletak pada aktivitas peserta didik untuk memecahkan masalah dengan menerapkan keterampilan meneliti, menganalisis, membuat sampai dengan mempresentasikan produk pembelajaran berdasarkan pengalaman nyata.

Langkah-langkah pendekatan project based learning (Hartono \& Asiyah, 2018) sebagai berikut: a) penentuan proyek, penentuan proyek dapat berupa tugas langsung atau dari permasalahan-permaslahan yang harus diselesaikan, b) perancangan langkah-langkah penyelesaian proyek, menyusun langkah-langkah kegiatan yang akan dalam penyelesaian tugas atau proyek, c) penyusunan jadwal pelaksanaan proyek meliputi penyusunan jadwal sesuai langkah-langkah untuk menyelesaikan tugas atau proyek yang telah ditentukan sebelumnya, d) penyelesaian proyek dengan fasilitasi dan monitoring guru. (Jalaluddin, 2016) menyebutkan bahwa langkah-langkah pendekatan project based learning terdiri dari: a) penentuan pertanyaan mendasar, b) mendesain perencanaan proyek, c) menyusun jadwal, d) memonitor siswa dan kemajuan proyek, e) menguji hasil, f) mengevaluasi pengalaman.

Pelaksanaan pembelajaran dengan pendekatan project based learning memiliki kelebihan yaitu mampu meningkatkan motivasi belajar siswa, keterampilan meningkatkan motivasi belajar, meningkatkan keterampilan siswa dalam mengelola berbagai sumnber belajar, mendorong siswa lebih aktif dalam belajar, menumbuhkan kolaborasi antar siswa, meningkatkan kemampuan komunikasi, melatih siswa dalam mengorganisasi sebuah proyek, meningkatkan keterampilan dalam manajemen waktu, dan pembelajaran menyenangkan (Fahrezi, Taufiq, Akhwani, \& Nafi'ah, 2020). Kelemahan pendekatan project based learning antara lain kondisi kelas sulit dikondisikan sehingga kurang kondusif, siswa mengalami kesulitan dalam percobaan dan pengumpulan informasi, dan adanya kemungkinan siswa yang kurang aktif dalam kerja kelompok (Suciani et al., 2018).

Tujuan penelitian tindakan kelas yaitu a) untuk mengetahui apakah terdapat peningkatan kreativitas belajar siswa pada pembelajaran tematik menggunakan pendekatan Project Based Learning. b) untuk mengetahui bagaimana langkah-langkah pendekatan Project Based Learning yang dapat meningkatkan kreativitas siswa dalam pembelajaran tematik.

\section{METODE PENELITIAN}

Penelitian ini merupakan penelitian tindakan kelas (PTK). Subjek dalam penelitian ini yaitu siswa kelas 5 SDN 2 Tambirejo Kecamatan Toroh Kabupaten Grobogan. Penelitian dilaksanakan pada semester II tahun pelajaran 2020/2021. Model PTK yang digunakan yaitu spiral dari Kemmis dan MC Taggart. Prosedur penelitian terdiri dari 2 siklus dimana masing-masing siklus terdapat 3 tahapan yaitu 1) perencanaan, 2) pelaksanaan dan pengamatan, 3) refleksi. Prosedur penelitian secara rinci dijelaskan melalui gambar 1 berikut ini. 
1882 Peningkatan Kreativitas Siswa Pada Pembelajaran Tematik Menggunakan Pendekatan Project Based Learning - Lilis Setiawan, Naniek Sulistya Wardani, Trifosa Intan Permana

DOI: https://doi.org/10.31004/basicedu.v5i4.1068

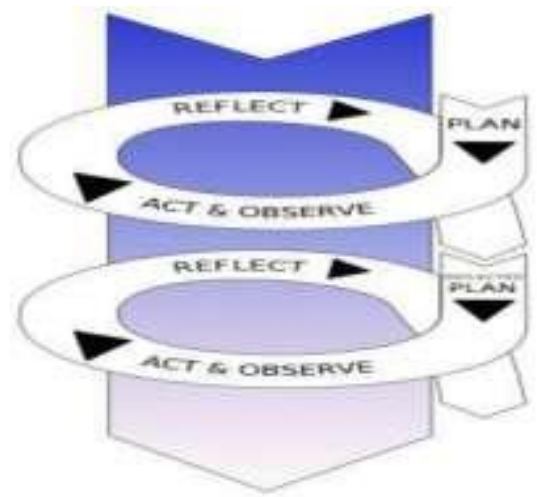

\section{Gambar 1. PTK Model Spiral Stephen Kemmis dan Robin Mc. Taggart}

Langkah-langkah project based learning untuk meningkatkan kreativitas belajar siswa dengan Tema 6 Panas dan Perpindahannya Subtema 2 dan 3 terdiri dari: a) Pembelajaran dimulai dengan pertanyaan "Mengapa baju yang basah apabila dijemur dibawah sinar matahari bisa kering?", b) Merencanakan proyek pembuatan video percobaan proses perpindahan panas, c) Menyusun jadwal aktivitas selama proses pembuatan video percobaan proses perpindahan panas, d) Mengawasi jalannya proses pembuatan video percobaan perpindahan panas, e) Penilaian pada video hasil percobaan proses perpindahan panas, f) Mengevaluasi hasil percobaan perpindahan panas, Pada akhir proses pembelajaran melakukan refleksi terhadap aktivitas percobaan perpindahan panas.

Teknik pengumpulan data dalam penelitian ini yaitu non tes (observasi). Instrumen berupa lembar observasi. Teknik analisis data yang digunakan adalah analisis statistik deskriptif komparatif yaitu teknik yang digunakan untuk membandingkan kreativitas belajar dari pra siklus, siklus I dan siklus II. Kisi-kisi pengukuran kreativitas belajar siswa secara rinci disajikan dalam table 1 berikut.

Tabel 1

Kisi-Kisi Pengukuran Kreativitas Belajar

\begin{tabular}{|c|c|c|c|}
\hline No & $\begin{array}{l}\text { Kriteria Kreativitas } \\
\text { Belajar }\end{array}$ & Kegiatan & Skor \\
\hline \multirow[t]{2}{*}{1} & $\begin{array}{l}\text { Keterampilan } \\
\text { lancar }\end{array}$ & $\begin{array}{l}\text { Peserta didik mampu mengidentifikasi masalah } \\
\text { tentang proses perpindahan panas }\end{array}$ & 1 \\
\hline & & $\begin{array}{l}\text { Peserta didik mampu membuat pertanyaan tentang } \\
\text { proses perpindahan panas }\end{array}$ & 1 \\
\hline \multirow[t]{2}{*}{2} & $\begin{array}{l}\text { Keterampilan } \\
\text { luwes }\end{array}$ & $\begin{array}{l}\text { Peserta didik mampu merumuskan masalah tentang } \\
\text { proses panas dan perpindahannya }\end{array}$ & 1 \\
\hline & & $\begin{array}{l}\text { Peserta didik mampu membuat hipotesis tentang } \\
\text { proses perpindahan panas }\end{array}$ & 1 \\
\hline \multirow[t]{2}{*}{3} & $\begin{array}{l}\text { Keterampilan } \\
\text { orisinal }\end{array}$ & $\begin{array}{l}\text { Peserta didik mampu bekerjasama dalam kelompok } \\
\text { diskusi }\end{array}$ & 1 \\
\hline & & $\begin{array}{l}\text { Peserta didik mampu menyusun jadwal penyelesaian } \\
\text { proyek tentang proses perpindahan panas }\end{array}$ & 1 \\
\hline \multirow[t]{2}{*}{4} & $\begin{array}{l}\text { Keterampilan } \\
\text { mengelaborasi }\end{array}$ & $\begin{array}{l}\text { Peserta didik mampu mengumpulkan informasi dari } \\
\text { berbagai sumber/referensi tentang proses } \\
\text { perpindahan panas }\end{array}$ & 1 \\
\hline & & $\begin{array}{l}\text { Peserta didik mampu menganalisis data yang telah } \\
\text { berhasil dikumpulkan tentang proses perpindahan } \\
\text { panas }\end{array}$ & 1 \\
\hline \multirow[t]{2}{*}{5} & Keterampilan menilai & $\begin{array}{l}\text { Peserta didik mampu mempresentasikan hasil proyek } \\
\text { tentang proses perpindahan panas }\end{array}$ & 1 \\
\hline & & $\begin{array}{l}\text { Peserta didik mampu membuat kesimpulan dari hasil } \\
\text { proyek tentang proses perpindahan panas }\end{array}$ & 1 \\
\hline
\end{tabular}


1883 Peningkatan Kreativitas Siswa Pada Pembelajaran Tematik Menggunakan Pendekatan Project Based Learning - Lilis Setiawan, Naniek Sulistya Wardani, Trifosa Intan Permana

DOI: https://doi.org/10.31004/basicedu.v5i4.1068

\section{HASIL DAN PEMBAHASAN PENELITIAN}

Peningkatan kreativitas belajar siswa kelas 5 diupayakan dengan pemberian tindakan berupa pendekatan project based learning. Penelitian ini dilakukan dengan menggunakan dua siklus yakni siklus 1 dan siklus 2 . Setiap siklus terdiri dari 3 tahap yaitu: tahap perencanaan, tahap pelaksanaan serta observasi, dan tahap refleksi.

Tahap 1 yaitu tahap perencanan tindakan. Tahap 1 diawali dengan menyusun perangkat pembelajaran tema panas dan perpindahannya subtema 2. Perpindahan kalor disekitar kita dan subtema 3. Pengaruh kalor terhadap kehidupan. Muatan pembelajaran yaitu PPKn, Bahasa Indonesia dan IPA. Perangkat pembelajaran yang disiapkan pada tahap 1 yaitu terdiri dari Rencana Pelaksanaan Pembelajaran (RPP), materi, media pembelajaran, lembar kegiatan peserta didik (LKPD) dan evaluasi. RPP disusun berdasarkan permasalahan panas dan perpindahannya. LKPD disusun untuk memberikan kegiatan kelompok yang akan dilakukan dalam mempelajari tema panas dan perpindahannya.

Tahap ke-2 yaitu implementasi perangkat pembelajaran yang telah disiapkan. Proses pelaksanaan pembelajaran yang dilakukan akan diobservasi oleh teman sejawat. Observasi dilakukan untuk mengetahui keterlaksanaan pembelajaran apakah sudah sesuai dengan perangkat pembelajaran yang telah dirancang sebelumnya. Penilaian kesesuaian pelaksanaan pembelajaran dengan perangkat pembelajaran yang telah disusun menggunakan lembar observasi. Selain itu, observasi dilakukan untuk memudahkan evaluasi dalam pelaksanaan pembelajaran selanjutnya. Kegiatan pembelajaran berisi kegiatan pendahuluan, kegiatan inti, dan kegiatan penutup. Kegiatan pembelajaran diawali dengan diberikan link pertemuan kepada peserta didik melalui pesan grup WhatsApp. Setelah semua peserta didik dapat mengakses link yang telah diberikan maka pembelajaran akan dimulai. Tahap pertama yang akan dilakukan dalam pembelajaran dengan pendekatan project based learning yaitu tahap pendahuluan. Pada tahap pendahuluan peserta didik bersama guru melakukan doa pembuka pembelajaran dan dilanjutkan guru melakukan presensi kehadiran peserta didik. Guru melanjutkan dengan melakukan apresepsi pembelajaran serta menyampaikan tujuan pembelajaran.

Tahap yang kedua yaitu tahap kegiatan inti. Pada tahap ini guru menyampaikan materi yang akan dipelajari, dalam pelaksanan pembelajaran guru bertugas sebagai fasilitator yang memfasilitasi peserta didik untuk mampu melaksanakan pembelajaran dengan kreativitas melalui tahap 1). mengidentifikasi masalah tentang proses perpindahan panas, 2) membuat pertanyaan terkait proses perpindahan panas, 3) merumuskan masalah tentang proses panas dan perpindahannya, 4) membuat hipotesis tentang proses perpindahan panas, 5) bekerjasama dalam kelompok diskusi. 6) menyusun jadwal penyelesaian proyek tentang proses perpindahan panas, 7) mengumpulkan informasi dari berbagai sumber/referensi tentang proses perpindahan panas, 8) menganalisis data yang telah berhasil dikumpulkan tentang proses perpindahan panas, 9) mempresentasikan hasil proyek proses perpindahan panas, 10) membuat kesimpulan dari hasil proyek proses perpindahan panas. Kegiatan pembelajarn tersebut melatih peserta didik untuk mampu membuat pertanyaan, merencanakan proyek pembuatan video percobaan proses perpindahan panas, menyusun jadwal aktivitas selama proses pembuatan video percobaan proses perpindahan panas, mengawasi jalannya proses pembuatan video percobaan perpindahan panas, melakukan penilaian video hasil percobaan proses perpindahan panas, dan mengevaluasi hasil percobaan perpindahan panas dengan memberikan kesimpulan.

Tahap ketiga yaitu tahap refleksi. Tahap refleksi dilakukan setelah pelaksanaan pembelajaran selesai. Pada tahap ini peserta didik dan guru secara bersama-sama melakukan refleksi terhadap kegiatan proyek pembuatan video percobaan proses perpindahan panas dan hasil proyek yang dilakukan. Kemudian menyimpulkan hasil pembelajaran yang telah dilakukan. Untuk mengetahui tingkat pemahaman siswa terhadap materi yang telah dipelajari maka diberikan soal sebagai bentuk evaluasi pembelajaran. Untuk mengakhiri kegiatan pembelajaran guru tidak lupa untuk melaksanakan doa bersama yang dipimpin oleh salah satu peserta didik.

Kelemahan yang terjadi pada pembelajaran siklus 1 yaitu pelaksanaan pembelajaran belum maksimal, guru belum sepenuhnya menjadi fasilitator, terdapat empat siswa yang tidak fokus dalam mengumpulkan data 
1884 Peningkatan Kreativitas Siswa Pada Pembelajaran Tematik Menggunakan Pendekatan Project Based Learning - Lilis Setiawan, Naniek Sulistya Wardani, Trifosa Intan Permana

DOI: https://doi.org/10.31004/basicedu.v5i4.1068

melalui pengamatan pada kegiatan percobaan proses perpindahan panas. Selain itu, terdapat 6 siswa pada saat mengumpulkan data melalui pengamatan tidak bekerjasama dengan kelompok, sehingga konsep pembelajaran berpusat pada siswa belum dapat terlaksana dengan baik. Berdasarkan pada hasil evaluasi kegiatan pembelajaran siklus 1, maka pada pelaksanaan pembelajaran siklus 2 guru sudah mampu menjadi fasilitator pada proses pembelajaran. Guru jauh lebih siap dalam pelaksanan pembelajaran. Pada siklus 2 kegiatan pembelajaran diberikan aturan agar pembelajaran yang dilakukan dapat menjaga kondisi kelas tetap kondusif. Pada siklus 2 peserta didik telah terlibat dalam proses pembelajaran, serta dapat bekerjasama dengan kelompok masing-masing.

Hasil penelitian kreativitas belajar siswa pra siklus, siklus 1 dan siklus 2 , secara rinci disajikan melalui tabel 2.

Tabel 2

Distribusi Frekuensi Kreativitas Bealajar Siswa Pra Siklus, Siklus I, Siklus II

\begin{tabular}{cccccccc}
\hline $\begin{array}{c}\text { Skor } \\
\text { Kreativitas }\end{array}$ & Kriteria & \multicolumn{2}{c}{ Pra Siklus } & \multicolumn{2}{c}{ Siklus I } & \multicolumn{2}{c}{ Siklus II } \\
\hline & & F & $\mathbf{( \% )}$ & F & $\mathbf{( \% )}$ & F & $(\boldsymbol{\%})$ \\
\hline $8-10$ & Tinggi & 7 & 33,33 & 11 & 52,38 & 17 & 80,95 \\
\hline $5-7$ & Sedang & 5 & 23,81 & 6 & 28,57 & 4 & 19,05 \\
\hline $2-4$ & Rendah & 9 & 42,86 & 4 & 19,05 & 0 & 0 \\
\hline Jumlah & & 21 & 100 & 21 & 1100 & 21 & 100 \\
\hline
\end{tabular}

Sumber : Data Primer

Berdasarkan pada Tabel 2 dapat dilihat bahwa pada tahap prasiklus terdapat 7 peserat yang memiliki kriteria kreativitas tinggi dengan presentase 33,33\% dari 21 siswa, pada tahap siklus I terdapat 11 siswa yang memiliki kriteria kreativitas tinggi dengan presentase 52,38\% dari 21 siswa, dan pada siklus II terdapat 17 siswa yang memiliki kriteria kreativitas tinggi dengan presentase 80,95\% dari 21 siswa. Peningkatan kreativitas belajar siswa disebabkan karena pemberian tindakan berupa pembelajaran yang didesain dengan menggunakan pendekatan project based learning. Hal tersebut didukung dengan hasil kreativitas belajar yang diperoleh setelah memakai desain pembelajaran pendekatan project based learning bahwa terdapat penambahan sebanyak empat siswa dengan kategori kreativitas belajar tinggi pada siklus I dan penambahan sebanyak enam siswa dengan kategori kreativitas belajar tinggi pada siklus II. Upaya yang dilakukan dalam meningkatakan kreativitas belajar siswa yaitu dengan memberi tindakan pembelajaran menggunakan pendekatan project based learning. Pendekatan project based learning menggunakan langkahlangkah sebagai berikut: a) Pembelajaran dimulai dengan pertanyaan "Mengapa baju yang basah apabila dijemur dibawah sinar matahari bisa kering?", b) Merencanakan proyek pembuatan video percobaan proses perpindahan panas, c) Menyusun jadwal aktivitas selama proses pembuatan video percobaan proses perpindahan panas, d) Mengawasi jalannya proses pembuatan video percobaan perpindahan panas, e) Penilaian pada video hasil percobaan proses perpindahan panas, f) Mengevaluasi hasil percobaan perpindahan panas, Pada akhir proses pembelajaran melakukan refleksi terhadap aktivitas percobaan perpindahan panas.

Pemantapan peningkatan kreativitas belajar siswa dilakukan dengan pemberian tindakan yang sama yaitu menggunakan pendekatan project based learning dengan materi berikutnya pada siklus II. Terlihat bahwa pada siklus II kreativitas belajar siswa dengan kategori tinggi terdapat 17 siswa dan tidak tedapat siswa dengan kriteria kreativitas belajar rendah. Kreativitas belajar mengalami peningkatan karena ada pemberian tindakan. Peningkatan kreativitas belajar siswa disebabkan karena pemberian tindakan sama dengan sebelumnya sehingga siswa mulai terbiasa dengan kegiatan pembelajaran dilakukan.

Penerapan pembelajaran project based learning yang didesain dengan menggunakan media pembelajaran dan strategi pembelajaran yang tepat dapat meningkatkan kreativitas siswa (Bahrudin, 2018). Peningkatan kreativitas belajar siswa sejalan dengan hasil penelitian yang dilaksanakan (Natty, Kristin, \& Anugraheni, 2019) yang menunjukan bahwa terdapat peningkatan kreativitas dan hasil belajar melalui model 
1885 Peningkatan Kreativitas Siswa Pada Pembelajaran Tematik Menggunakan Pendekatan Project Based Learning - Lilis Setiawan, Naniek Sulistya Wardani, Trifosa Intan Permana

DOI: https://doi.org/10.31004/basicedu.v5i4.1068

pembelajaran Project Based Learning pada siswa kelas 3 SD. Temuan lain disampaikan (Lydiati, 2019) bahwa terdapat peningkatan kreativitas peserta didik dalam menyelesaikan permasalahan pada materi statistik dengan menggunakan model PjBL-STEM, dimana penggunaan model tersebut dapat melatih siswa untuk menghasilkan ide-ide kreatif melalui penalaran, melakukan asosiasi, serta mengungkapkan kembali pengetahuan yang dimiliki sebelumnya untuk menyelesaiakan masalah. Hasil penelitian (Sari, Manzilatusifa, \& Handoko, 2019) menyimpulkan bahwa penerapan model pembelajaran project based learning dapat meningkatkan kemampuan berpikir kreatif siswa pada kategori sedang. Sejalan dengan penelitian (Yani \& Taufik, 2020) yang menyimpulkan bahwa penerapan model project based learning pada pembelajaran tematik terpadu dapat membuat siswa lebih kreatif, percaya diri, dan mampu bekerja mandiri atau berkelompok dalam menyelesaikan suatu proyek.

Peningkatan kreativitas belajar siswa dalam penelitian ini disebabkan oleh esensi dari pendekatan project based learning yakni lebih melibatkan siswa aktif dalam proses pembelajaran, siswa bekerja sama dengan membentuk kelompok dalam memecahkan masalah serta menghasilkan suatu proyek dalam proses pembelajaran. Pendekatan project based learning merupakan pendekatan inovatif yang memfokuskan pada belajar kontekstual melalui kegiatan yang kompleks. Kegiatan kompleks berdasarkan pada pertanyaan dan permasalahan yang sangat menantang dan menuntut siswa untuk merancang, memecahkan masalah, membuat keputusan serta memberikan kesempatan kepada siswa untuk bekerja secara mandiri.

Pendekatan project based learning difokuskan dalam pemecahan masalah yang menjadi tujuan utama dari proses belajar sehingga dapat memberikan pembelajaran yang lebih bermakna karena dalam belajar tidak hanya mengerti apa yang dipelajari tetapi membuat peserta didik menjadi tahu apa manfaat dari pembelajaran tersebut untuk lingkungan sekitarnya. Selain itu, Kelebihan pendekatan project based learning adalah: (1) Menumbuhkan kemandirian siswa, (2) Memiliki tanggung jawab yang besar untuk pembelajaran mereka sendiri, (3) Mengembangkan keterampilan dalam pemecahan masalah, (4) Memperluas akses untuk belajar.

Berdasarkan paparan tersebut dapat disimpulkan bahwa terdapat peningkatan kreativitas belajar siswa kelas 5 yang diupayakan dengan pendekatan project based learning. Tetapi dalam pelaksanaanya penelitian terdapat temuan dalam penerapan pendekatan project based learning pada siswa SD yaitu siswa sulit untuk dikondisikan dalam pengerjaan proyek, pengerjaan proyek yang memakan waktu lama, pembagian tugas proyek yang masih kurang seimbang karena terdapat siswa yang tidak ikut mengerjakan tugas proyek, dan pengerjaan tugas proyek masih bergantung oleh guru.

\section{KESIMPULAN}

Berdasarkan hasil penelitian dan pembahasan tersebut dapat disimpulkan bahwa terdapat peningkatan kreativitas belajar siswa kelas 5 yang diupayakan dengan pendekatan project based learning, didukung dengan hasil oleh hasil kreativitas belajar siswa pada siklus 1 yang menunjukkan terdapat 52,38\% dari 21 siswa memiliki kriteria kreativitas tinggi mengalami peningkatan menjadi 80,95\% dari 21 siswa memiliki kriteria kreativitas tinggi pada siklus 2. Peningkatan kreativitas belajar siswa dengan pendekatan project based learning diupayakan dengan menggunakan langkah pembelajaran dimulai dengan memberikan pertanyaan, merencanakan proyek pembuatan video percobaan proses perpindahan panas, menyusun jadwal aktivitas selama proses pembuatan video percobaan, mengawasi jalannya proses pembuatan video percobaan, penilaian pada video hasil percobaan, evaluasi hasil percobaan dengan melakukan refleksi terhadap aktivitas percobaan perpindahan panas. Melalui pendekatan project based learning peserta didik terlatih menghadapi masalah, mendiskusikan rencana pemecahanya, memecahkan masalah, dan tanggap akan permasalahan yang dihadapi. 


\section{DAFTAR PUSTAKA}

Agustiana, I. G. A. T., Agustini, R., Ibrahim, M., \& Tika, I. N. (2020). Efektivitas Model OPPEMEI untuk Meningkatkan Kemampuan Berpikir Kreatif Mahasiswa. Journal of Education Technology, 4(2), 150160. https://doi.org/10.23887/jet.v4i2.25343

Alzoubi, A. M., Al Qudah, M. F., Albursan, I. S., Bakhiet, S. F., \& Abduljabbar, A. S. (2016). The Effect of Creative Thinking Education in Enhancing Creative Self-Efficacy and Cognitive Motivation. Journal of Educational and Developmental Psychology, 6(1), 117-130. https://doi.org/10.5539/jedp.v6n1p117

AM, I. A., Saputra, S. Y., \& Amelia, D. J. (2017). Pelaksanaan Pembelajaran Tematik Sesuai Kurikulum 2013 di SD Muhammadiyah 03 Wajak. ELSE (Elementary School Education Journal), 1(1), 67-76.

Astuti, R., \& Aziz, T. (2019). Integrasi Pengembangan Kreativitas Anak Usia Dini di TK Kanisius Sorowajan Yogyakarta. Jurnal Obsesi : Jurnal Pendidikan Anak Usia Dini, 3(2), 294. https://doi.org/10.31004/obsesi.v3i2.99

Bahrudin. (2018). Penerapan Model Pembelajaran Berbasis Proyek Dengan Hasil Belajar Siswa Sekolah Dasar (The Uses of Project-Based Learing Model by Utilizing ICT Media to Increase the Creativity and Student's Learning Outcome in Primary School). Jurnal Teknologi Pendidikan Dan Pembelajaran, 5(2), $131-139$.

Ernawati, M. D. W., M, D., Asrial, \& Muhaimin. (2019). Development of Creative Thinking Skill Instruments for Chemistry Student Teachers in Indonesia. International Journal of Online and Biomedical Engineering, 15(14), 21-30. https://doi.org/10.3991/ijoe.v15i14.11354

Fahrezi, I., Taufiq, M., Akhwani, A., \& Nafia'ah, N. (2020). Meta-Analisis Pengaruh Model Pembelajaran Project Based Learning Terhadap Hasil Belajar Siswa Pada Mata Pelajaran IPA Sekolah Dasar. Jurnal Ilmiah Pendidikan Profesi Guru, 3(3), 408-4016. https://doi.org/10.23887/jippg.v3i3.28081

Handajani, S., Pratiwi, H., \& Mardiyana. (2018). The 21 st Century Skills with Model Eliciting Activities on Linear Program. Journal of Physics: Conference Series, 1008(1), 1-7. https://doi.org/10.1088/1742$6596 / 1008 / 1 / 012059$

Hariyanto, \& Warsono. (2012). Pembelajaran Aktif Teori dan Assesment. PT Remaja Rosda Karya.

Hartono, D. P., \& Asiyah, S. (2018). PjBL Untuk Meningkatkan Kreativitas Mahasiswa: Sebuah Kajian Deskriptif Tentang Peran Model Pembelajaran PJBL Dalam Meningkatkan. Jurnal Dosen Universitas PGRI Palembang, 2(1), 1-11. https://jurnal.univpgri-palembang.ac.id/index.php/prosiding/index

Jalaluddin. (2016). Model-model Pembelajaran dan Implementasi dalam RPP. Media Mutiara Lentera.

Lydiati, I. (2019). Peningkatan Kreativitas Peserta Didik pada Materi Statistika Melalui Model Pembelajaran PjBL-STEM Kelas XII MIPA 6 SMA Negeri 7 Yogyakarta. Jurnal Ideguru, 4(2), 51-60. https://jurnaldikpora.jogjaprov.go.id/index.php/jurnalideguru/article/view/94

Mashitoh, N. L. D., Sukestiyarno, Y., \& Wardono, W. (2021). Creative Thinking Ability Based on Self Efficacy on an Independent Learning Through Google Classroom Support. Journal of Primary Education, 10(1), 79-88.

Munandar, U. (2009). Pengembangan Kreativitas Anak Berbakat. PT Gramedia Utama.

Natty, R. A., Kristin, F., \& Anugraheni, I. (2019). Peningkatkan Kreativitas Dan Hasil Belajar Siswa Melalui Model Pembelajaran Project Based Learning di Sekolah Dasar. Jurnal Basicedu, 3(4), 1082-1092. https://doi.org/10.31004/basicedu.v3i4.262

Nurul 'azizah, A., \& Wardani, N. S. (2019). Upaya Peningkatan Hasil Belajar Matematika Melalui Model Project Based Learning Siswa Kelas V SD. Jurnal Riset Teknologi Dan Inovasi Pendidikan, 2(1), 194 204.

Nuryati, \& Yuniawati, N. (2019). Peningkatan Kreativitas Pada Anak Usia Dini Kelas SD Awal Usia 6-8 Tahun Melalui Metode Praktikum Membatik. As-Sibyan: Jurnal Pendidikan Anak Usia Dini, 4(1), 1-10. 
1887 Peningkatan Kreativitas Siswa Pada Pembelajaran Tematik Menggunakan Pendekatan Project Based Learning - Lilis Setiawan, Naniek Sulistya Wardani, Trifosa Intan Permana

DOI: https://doi.org/10.31004/basicedu.v5i4.1068

Putria, H., Maula, L. H., \& Uswatun, D. A. (2020). Analisis Proses Pembelajaran dalam Jaringan (DARING) Masa Pandemi Covid- 19 Pada Guru Sekolah Dasar. Jurnal Basicedu, 4(4), 861-870.

https://doi.org/10.31004/basicedu.v4i4.460

Rusadi, B. E., Widiyanto, R., \& Lubis, R. R. (2019). Analisis Learning and Inovation Skills Mahasiswa Pai Melalui Pendekatan Saintifik Dalam Implementasi Keterampilan Abad 21. Jurnal Conciencia, 19(2), 112-131. https://doi.org/10.19109/conciencia.v19i2.4323

Sari, S. P., Manzilatusifa, U., \& Handoko, S. (2019). Penerapan Model Project Based Learning (PjBL) Untuk Meningkatkan Kemampuan Berfikir Kreatif Peserta Didik. Jurnal Pendidikan Dan Pembelajaran Ekonomi Akuntansi, 5(2), 119-131.

Suciani, T., Lasmanawati, E., \& Rahmawati, Y. (2018). Pemahaman Model Pembelajaran Sebagai Kesiapan Praktik Pengalaman Lapangan (PPL) Mahasiswa Program Studi Pendidikan Tata Boga. Media Pendidikan, Gizi, Dan Kuliner, 7(1), 76-81.

Vera, M., \& Astuti, S. (2019). Peningkatan Kreativitas Dan Hasil Belajar Siswa Melalui Model Pembelajaran Problem Based Learning Pada Kelas Vsdn Sidorejo Lor V Salatiga. MAJU, 6(1), 11-21.

Wulandari, F. A., Mawardi, M., \& Wardani, K. W. (2019). Peningkatan Keterampilan Berpikir Kreatif Siswa Kelas 5 Menggunakan Model Mind Mapping. Jurnal Ilmiah Sekolah Dasar, 3(1), 10-16. https://doi.org/10.23887/jisd.v3i1.17174

Yani, L. I., \& Taufik, T. (2020). Penerapan Model Project Based Learning dalam Pembelajaran Tematik Terpadu di Kelas V Sekolah Dasar (Studi Literatur). E-Jurnal Inovasi Pembelajaran SD, 8(9), 70-82.

Yuniawardani, V., \& Mawardi. (2018). Peningkatan Hasil Belajar pada Pembelajaran Matematika dengan Model Problrm Based Learning Kelas IV SD. Jurnal Riset Teknologi Dan Inovasi Pendidikan, 1(2), 2432. 